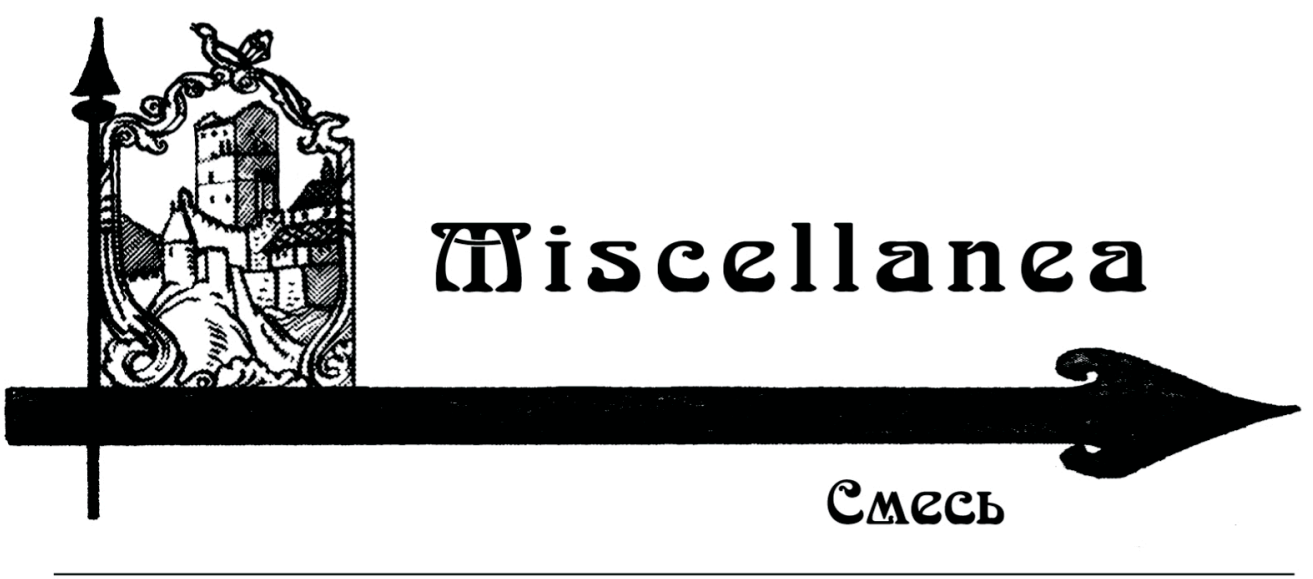

РЕКОНСТРУКЦИИ СЛАВЯНСКИХ ПОСЕЛЕНИЙ

СРеДНЕВеКОВЬЯ И РАННЕГо НовоГО ВРЕМЕНИ:

ИДЕИ И ИХ ВОПЛОЩЕНИЕ

УДК 94; ББК 63.3(4Пол); DOI https://doi.org/10.21638/spbu19.2021.106

W. Filipowiak, M. Bogacki, K. Kokora

\title{
THE CENTER OF SLAVS AND VIKINGS IN WOLIN, POLAND. HISTORY, SCENOGRAPHY, STORY AND EFFECT
}

\section{INTRODUCTION - WOLIN ARCHAEOLOGICAL SITE}

These days, Wolin is a small town in north-western Poland, located on the south-eastern end of Wolin Island. It has a long and rich history, dating back to the end of the $8^{\text {th }}$ century. The early medieval period, between the $8^{\text {th }}$ century and the $13^{\text {th }}$ century, was a golden age 
for the settlement, which at that time influenced the entire south Baltic Sea area, being a cultural melting pot, a meeting point for people from different parts of the world - Slavia, Scandinavia, Western and Central Europe and even the Arab world. All of that was reflected in many written records from that period, and in the plentiful and versatile archaeological material. The rich traditions of early medieval Wolin are also evidenced by the fact that most researchers identify it as the prototype of the legendary — Jómsborg, in the Scandinavian tradition, and Vineta, in the south Baltic Sea tradition. Early medieval Wolin was the subject of interest of various historians and archaeologists already in the $19^{\text {th }}$ century when numerous written accounts (western European, Scandinavian, or Arabic) were studied, and also first archaeological excavations took place. The $20^{\text {th }}$ century was a time of particular increase in archaeological investigations and research. Excavations are still being carried out at the site and in fact every expedition yields further interesting discoveries ${ }^{1}$. The results of these scientific investigations captured the imagination of not only Wolin residents, but from all over Poland and abroad. As a consequence, several institutions dedicated to the study and popularisation of the history of the town were established in Wolin: in 1952, the Archaeological Workshop of the Centre for Medieval Archaeology of the Baltic Region of the Institute of Archaeology and Ethnology of the Polish Academy of Sciences (at that time known as the Institute of History and Material Culture of the Polish Academy of Sciences, hereinafter the «Archaeological Workshop in Wolin»); in 1966, the Regional Museum (now the Andrzej Kaube Regional Museum), and 2008, the Wolin-Jomsborg-Vineta Centre of Slavs and Vikings (Centrum Stowian i Wikingów Wolin-Jomsborg-Vineta, hereinafter the «Centre»). Also of note, the Slav and Viking Festival (Festiwal Stowian i Wikingów, hereinafter the «Festival») has been taking place since 1993 - one of the biggest meetings of early medieval reenactors in Europe. The history of the Wolin open-air museum and the festivals is one of the best examples in Europe (and not just in Europe) of how one can use the cultural heritage of a given place for its popularisation and promotion and at the same time use the educational potential provided by historical reenactment.

\section{THE HISTORY}

The idea of building an open-air museum that would propagate the history of the town was first suggested in 1958 by Władysław Filipowiak, who at that time was the director of the National Museum in Szczecin and the head of archaeological excavations in Wolin ${ }^{2}$. The prospective heritage park was supposed to be the site for presenting reconstructed buildings from the Stone Age and the early Middle Ages, as well as ethnographic buildings.

The original location of the open-air museum was to be the remains of the Swedish bastion near the town center. Later, it was decided to move the location to Wzgórze Wisielców

${ }^{1}$ For information about Wolin see: Filipowiak Wt., Konopka M. The identity of a Town. Wolin, Town-State- $9^{\text {th }}-12^{\text {th }}$ Centuries // Quaestiones Medii Aevii Novae. 2008. Vol. 13. P. 243-288; Stanisławski B., Filipowiak Wt. (ed.) 1) Wolin wczesnośredniowieczny. Część 1. Warszawa, 2013. (Origines Polonorum. T. 6). 370 s.; 2) Wolin wczesnośredniowieczny. Część 2. Warszawa, 2014. (Origines Polonorum. T. 7). 459 s.; Rębkowski M. (ed.). Wolin — the Old Town. Szczecin, 2019. Vol. 1: Settlement Structure, Stratigraphy \& Chronology; Vol. 2: Studies on Finds.

${ }^{2}$ Kłosowska A., Stanisławski B. Gród na wyspie // Gazeta Rycerska. Wydanie Specjalne. 2008. S. 25 . 
(Hangmen Hill) on the southern outskirts of Wolin. According to the plans made at that time (Fig. 1), the archaeological part was supposed to hold the reconstruction of an early medieval harbour, houses built in different construction techniques, a street, and successive phases of ramparts. In addition to buildings, the museum was to present arts and crafts from c. $1000 \mathrm{AD}$. The ethnographic section was to hold around 50 houses, farm, utility, and religious buildings from the $19^{\text {th }}$ and $20^{\text {th }}$ centuries $^{3}$. That project was among the largest of its kind not only

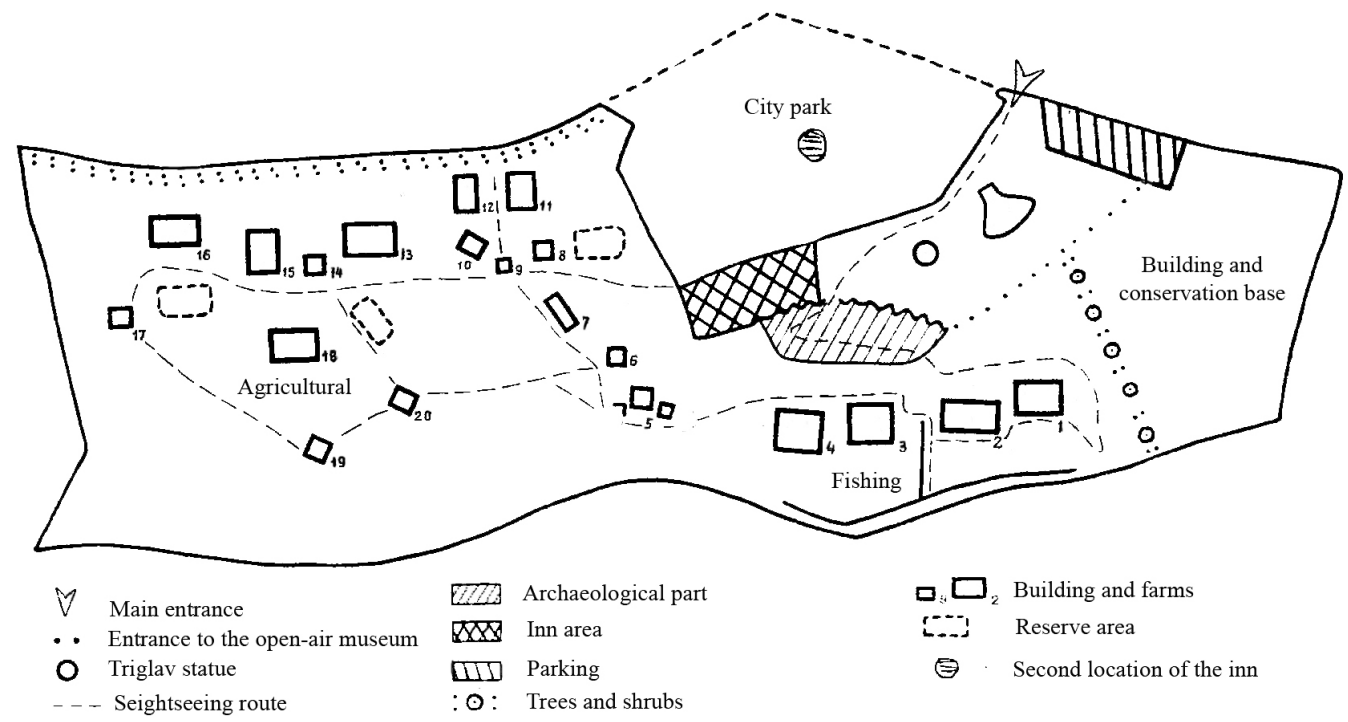

Fig. 1. Plan of the archaeological and ethnographical open-air museum in Wolin (State Archives in Szczecin, Międzyzdroje Branch, sygn. 13, digital processing W. Filipowiak)

in Poland but also in the whole of Central Europe. Unfortunately, those plans were never carried out; however, various other open-air events about early medieval Wolin were started as a result of the enthusiasm for the unrealized museum. In the 1970s and the 1980s, the Regional Museum and Cultural Centre in Wolin organized the «Raid of the Vikings on Wolin», a performance put on as a part of the Kupala Night celebrations, with the participation of representatives of all the villages in the district (Fig. 2). School kids dressed in costumes defended a village built on the Wolin commons, while members of the yachting club attacked from the water on fishing boats transformed into Viking ships. Residents unequivocally claimed that all participants wanted to be Wolinians, while the role of a Viking was perceived to be inferior - a role of a villain. In the 1970s, a reconstruction of a palisade and a display of the early medieval harbour were built in the town. All of that happened at a time when historical reenactment in Western Europe was only budding, and in Poland, it was virtually unknown.

In 1991, the «Wolin-Jomsborg. En Vikingetids-Handelsby i Polen» exhibition was created, which presented results of archaeological excavations carried out to date in Wolin

${ }_{3}^{3}$ Gerlach-Jósewicz A. Koncepcja wolińskiego parku etnograficznego-archeologicznego // Jantarowe Szlaki. R. 19. Nr 4-5 (154-155). 1976. S. 58-59. 
in the context of the Jomsborg legend. The organizers of the exhibition were the National Museum in Szczecin, the Archaeological Workshop in Wolin, and the Roskilde Museum in Denmark. That exhibition was presented in Roskilde, Lund, Esbjerg, Reykjavik, and Maribo in 1991-1993. It had a very wide reception in Scandinavian countries, in which the legend of Jomsborg is an element of their cultural heritage.

This exhibition became an inspiration for further actions. For instance, Professor Thomas Geoffrey Bibby (Fig. 3), a renowned archaeologist and one of the founding fathers of the early medieval Viking reenactment movement, contacted Professor Władysław Filipowiak and local authorities in Wolin. This resulted in the organisation in 1993 in Wolin of the first Viking Festival by the Danes (Fig. 4), with the help of the local authorities and numerous volunteers. Unlike the outdoor performances held from 1972-1992, that event was designed around the legend of Jomsborg and was intended to «revive the trade and cultural initiatives towards Eastern Europe, which first was taken by Harald Bluetooth 1000 years ago, highlight cultural contacts between Baltic and Nordic countries in the Viking era, spark the interest of the Poles in their historical relationships with Nordic countries and vice versa» ${ }^{4}$. In the first festival, alongside Goeffrey Bibby himself, several dozen reenactors from Scandinavia,

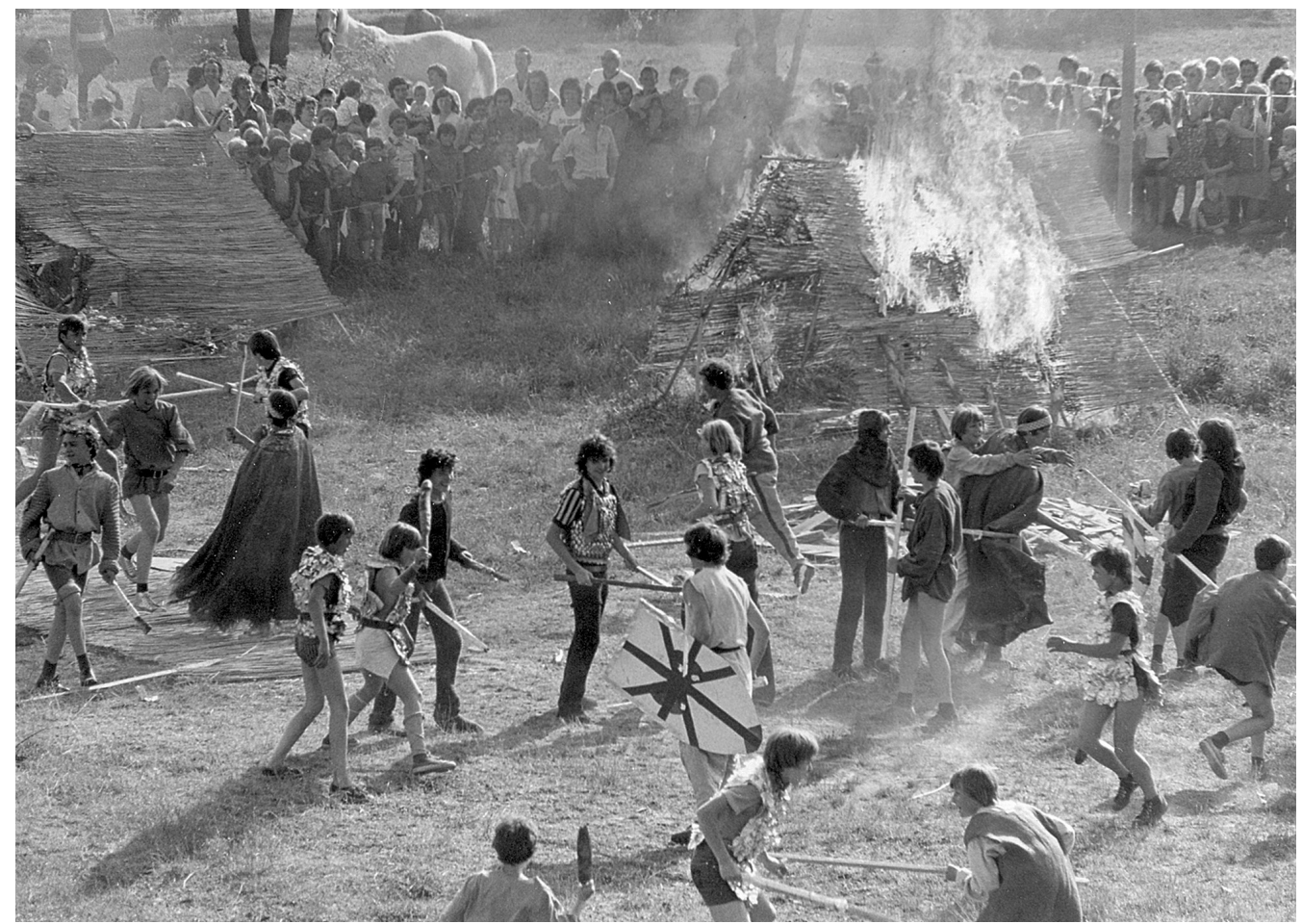

Fig. 2. «Raid of the Vikings on Wolin» in 1977 (Foto Archive of Wolin Regional Museum)

${ }^{4}$ Projektbeskrivelse from 16 february 1992, archive of Archaeological Workshop by the CABS IAE PAS. 
Germany, and the United Kingdom took part. In Poland, at that time, there were no early medieval reenactors.

The 1993 festival, the first event of its kind in Poland, was a great success for the town. The number of tourists who came to it exceeded the organizers' expectations. However, for the next two years, the festival was not held due for financial reasons. From 1996 to 1998 the town attempted to organize the event on its own, but it was more of a fair with historical elements. However, plans had already been made to develop the still small festival by adding a scenography linked to the early medieval settlement, which could be open to visitors outside the duration of the event itself as well. The author of one of the first concepts was Phil Burthem, who managed the first international Jomsborg Elag group (Fig. 5). All those projects came down to simplified ideas and visions of the early Middle Ages and were limited to creating a small stronghold surrounded with a palisade with a small gate tower and an inner enclosed area for putting up tents.

In 1999, Błażej Stanisławski, an archaeologist from the Archaeological Workshop in Wolin became involved with the organisation of the festival. Also, at that time a group of local residents established the «Dziedzictwo Wolina» («Wolin Heritage») association. The Festival was moved to the Wolińska Kępa island

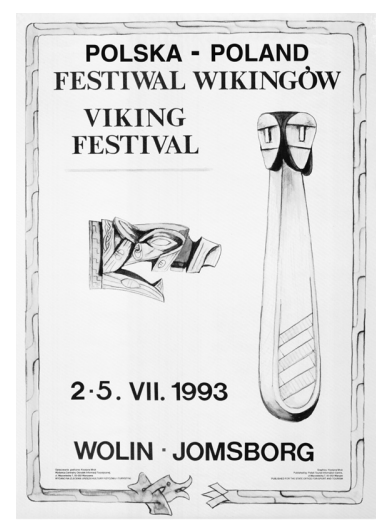

Fig. 4. Poster of the first Viking Festival in Wolin (Foto Archive of Communal Center for Culture, Sports,

Tourism and Recreation in Wolin) in the Dziwna Strait opposite the town center. The program strongly accented the Slavic character of Wolin, and the first permanent elements of the scenography were built - a fragment of the palisade on a small embank-

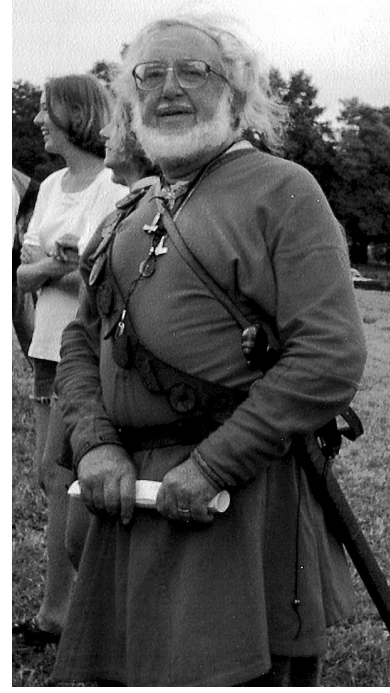

Fig. 3. Geoffrey Bibby in Wolin in 1993

(Foto Archive of Communal

Center for Culture, Sports,

Tourism and Recreation in Wolin) ment together with the gate tower (Fig. 6). In 2002, the WolinJomsborg-Vineta Slav and Viking Centre Association (hereinafter the «Association») was established, which absorbed part of the previous Wolin association. It brought together both history lovers - from Wolin, but also from other parts of the country - and archaeologists.

From the onset, the objective of the Association was, among other things, the construction of an open-air museum presenting the early medieval Wolin. The author of the first design was Błażej Stanisławski (Fig. 7) ${ }^{5}$. The project assumed the creation of at least 10 buildings in different construction techniques, pavilions for the presentation of various crafts, a palisade, and entrance gates. The entire complex was supposed to be built on the so-called «Small

${ }^{5}$ There are also opinions that Władysław Filipowiak supervised the project or cooperated on its creation: Kłosowska A., Stanisławski B. Gród na wyspie... S. 26. - Interviews with members of the Slavs and Vikings Association mention stories concerning the negotiations on various structural details with Władysław Filipowiak. It seems that it was very informal supervision based on his authority as the long-time Wolin scholar. However, it is difficult to establish which of his comments were actually taken on board and implemented. 

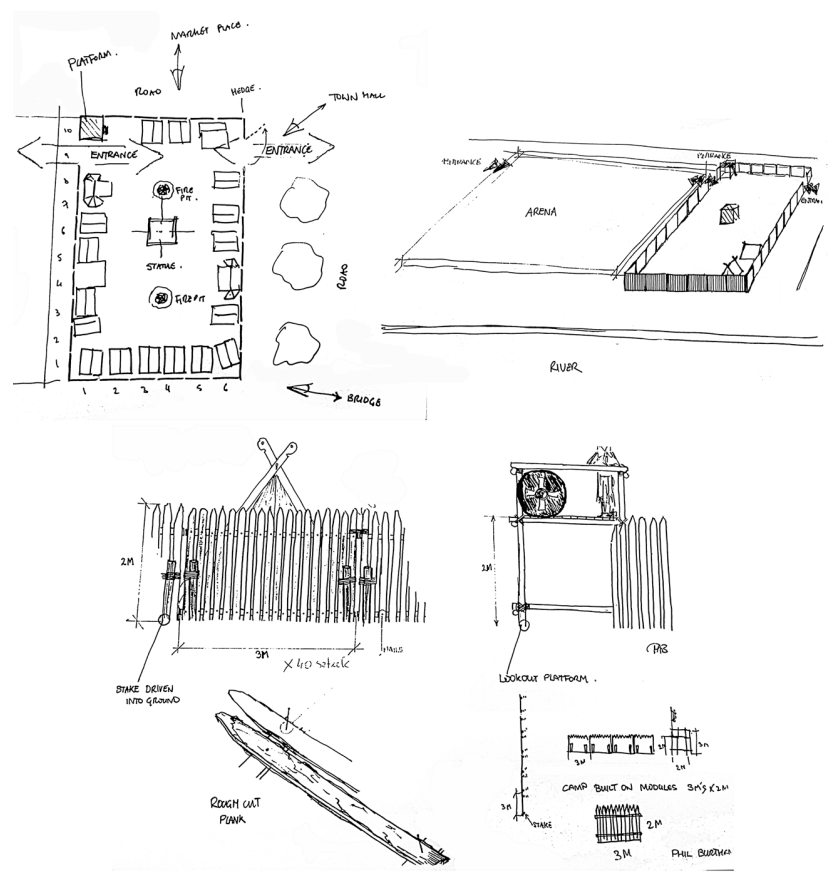

Fig. 5. Project of Viking theme park by Phil Burthem, 1998

(Foto Archive of Communal Center for Culture, Sports, Tourism and Recreation in Wolin, digital processing W. Filipowiak)

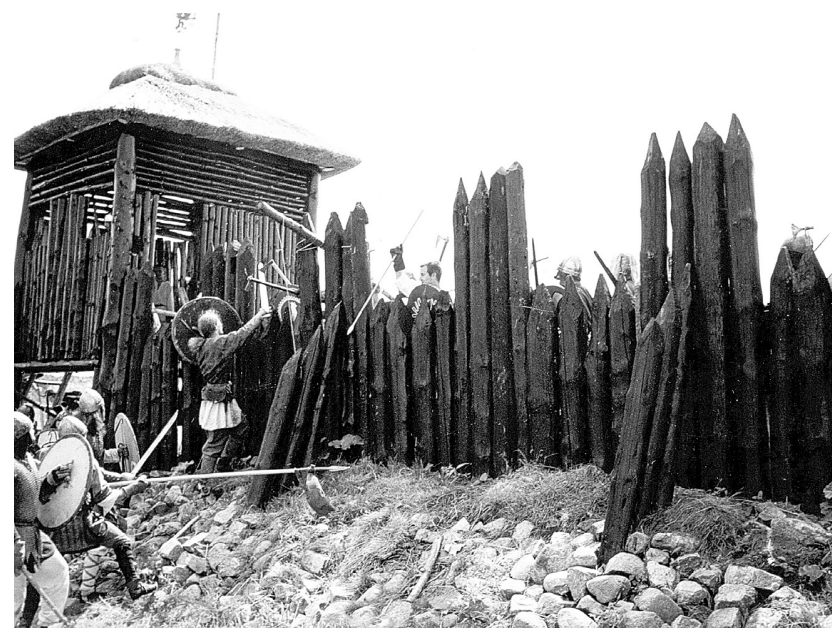

Fig. 6. Gate and rampart as a first scenography for the Viking Festival, 1999 (Foto Archive of Communal Center for Culture, Sports, Tourism and Recreation in Wolin)
Island» in Dziwna Strait, right next to Wolińska Kępa, where the Wolin Festival had taken place since 1999. However, the design for the Centre was modified by transferring it to Wolińska Kępa. In 2003, Błażej Stanisławski stepped down from his role in the organisation of the Festival and no longer worked with the Centre; from that time, the work was taken over solely by the Association, without the involvement of archaeologists.

Ultimately, the elements of the Centre put in place differed from the design. As a reason for that situation, their creators indicated health and safety and fire safety rules. Some details had to be changed (for instance, the size of door openings or the distance between the huts). The construction project, ordered by the Association, was prepared by Nabud, a company from Poznań ${ }^{6}$. The main architect was Krzysztof Sokołowski. Apart from changes in the historical part of the project, modernized features were added (e. g., toilets).

Further elements of the Centre were subsequently added as new external funding became available ${ }^{7}$. The official opening

${ }^{6}$ URL: http://www.nabud.pl/ projekty/inne/centrum-slowian-iwikingow-wolin---jomsborg---vineta (last visited - 07.08.2020). - Also verbal information provided by the head of the company, Jacek Nabzdyk.

${ }^{7}$ From the Small Regional Grants «Equal Opportunities» of Polska Fundacja Dzieci i Młodzieży and 
took place on 7 April 2008 - at that time, the Centre comprised 13 huts and a fragment of a rampart with the palisade and the gate. The same year saw the christening of the «Jumne Eagle» (Polish: Orzet Jumne) - a reconstruction of a ship from the $12^{\text {th }} / 13^{\text {th }}$ century from Kamien Pomorski, financed as a part of the international EU-funded project LAGOMAR.

In recent years, the Association built on the so-called «Small Island» (at the site of the original location of the open-air museum as planned by Błażej Stanisławski) a workshop,

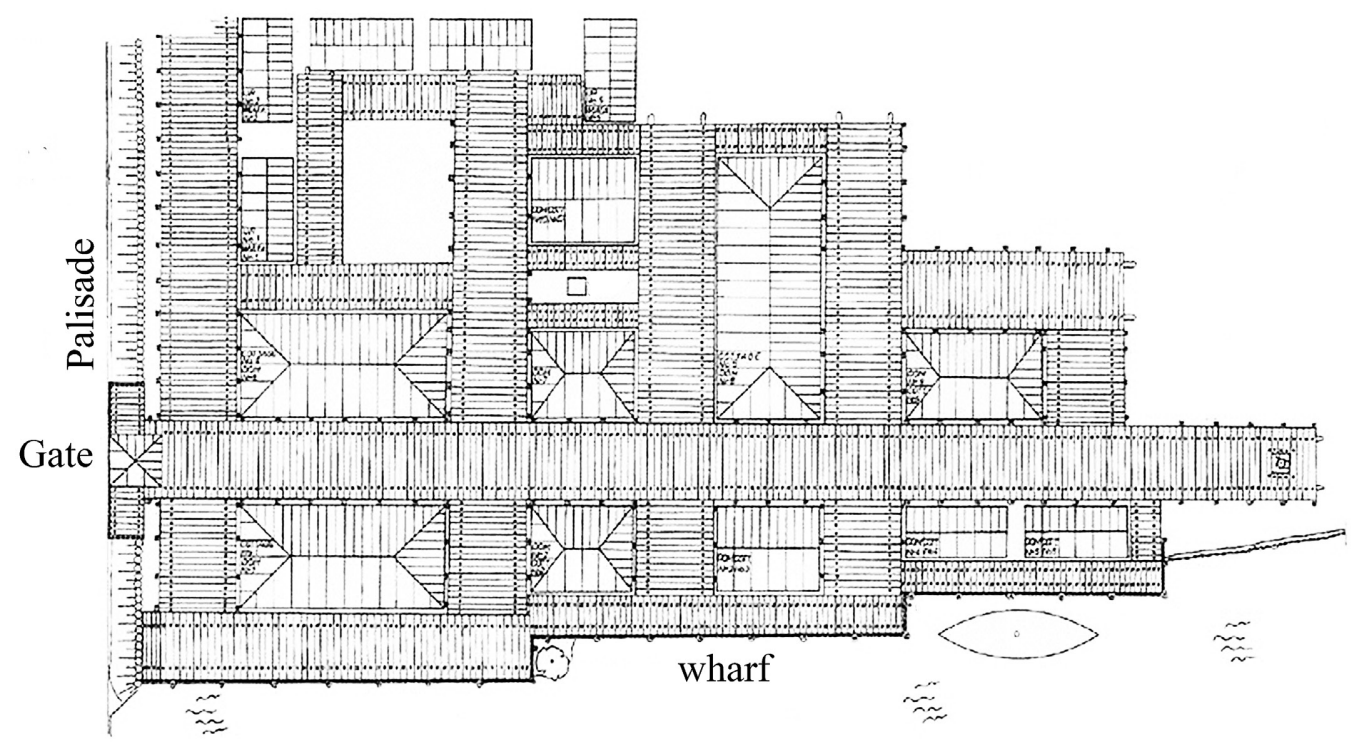

Fig. 7. First project by Błażej Stanisławski of open-air museum on the so-called «Small Island» (Foto Archive of Communal Center for Culture, Sports, Tourism and Recreation in Wolin)

conference building, and hotel cabins, styled as late medieval architecture. These structures are not a reconstruction of Wolin architecture from that period, and constitute a part of the commercial activity of the Association ${ }^{8}$.

\section{THE SCENOGRAPHY}

The Centre was created as scenography for the Slav and Viking Festival and subsequently was transformed into an open-air exhibition associated with the early medieval history of the town.

The Centre was designed as a settlement enclosed with a rampart with two gates and with an area of 1.5 hectares (Fig. 8). Inside the ramparts, there are clusters of buildings grouped by construction type: wattle and daub, log-house, palisade, vertical-post log, and post-and-beam

Polsko-Amerykańska Fundacja Wolności, from funds obtained from the Polish Ministry of Culture, grants from the Board of the Western Pomeranian Voivodeship.

${ }^{8}$ For more information about the history of the Festival and the Centre in a popular science context see: Bogacki M., Filipowiak W. Wolin, miasto Słowian i Wikingów. Historia wolińskich festiwali i nie tylko. Wolin, 2019. $196 \mathrm{p}$. 


1 post-and-beam houses
2 vertical-post log houses
3 palisade houses
4 log-house
5 wattle and daub houses
6 sheds
7 main gate
8 secondary gate
9 rampart
10 harbour
11 place of worship
12 runic stones

Fig. 8. Plan of the Wolin-Jomsborg-Vineta Centre of Slavs and Vikings (Google Maps, digital processing W. Filipowiak)

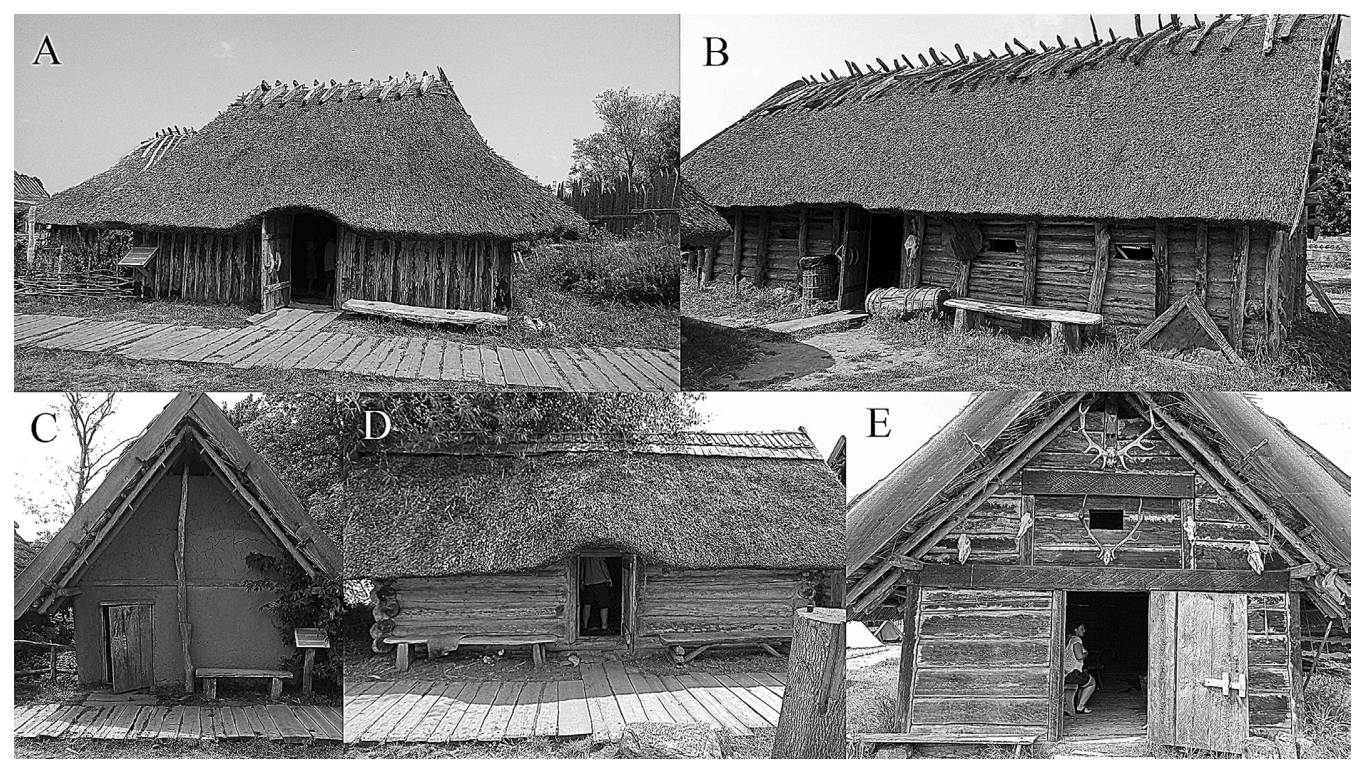

Fig. 9. Types of houses presented in the Centre: A - palisade house, B - post-and-beam house, $\mathrm{C}$ - wattle and daub house, D - log-house, E - vertical-post log house (Foto W. Filipowiak) 


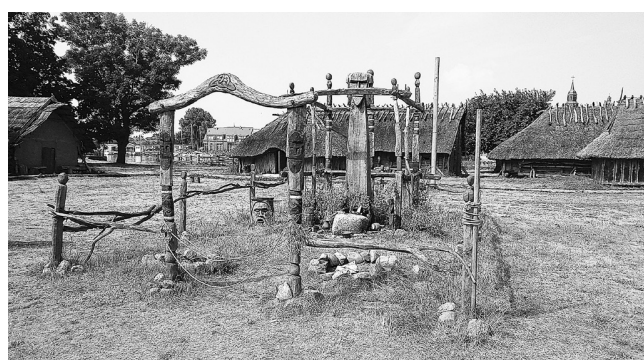

Fig. 10. Religious space instead of the originally planned temple (Foto W. Filipowiak)

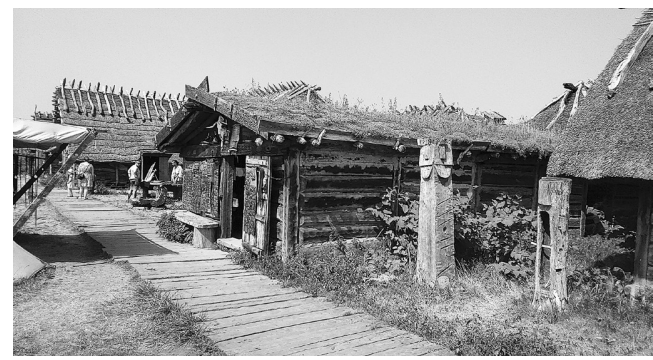

Fig. 11. Scandinavian hut with turf roof, house of the Scandinavian jeweler (Foto W. Filipowiak)

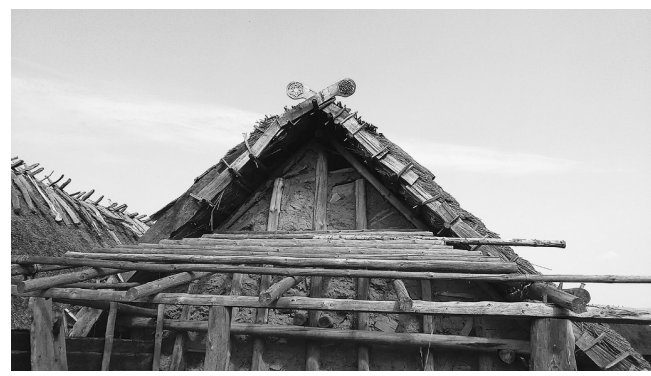

Fig. 12. The sign of the Galactic Empire (on the left) known from the "Star Wars" series on the rooftop of one of the huts (Foto W. Filipowiak) construction (Fig. 9), the presence of all these construction techniques in Wolin has been confirmed through archaeological excavations). Huts within the clusters were built as close to each other as possible, representing the dense architecture discovered during archaeological investigations in the center of the town. Thus, the exhibition presents different types of buildings recorded during the excavations, and is not a reconstruction of an actual part of the town from a specific period.

The northern section of the recreated settlement holds buildings and a religious space (Fig. 10, instead of the originally planned temple), while in its southern part there is a site with pavilions for craftsmen and putting up tents by the attendees of the Festival. In front of the main gate, there are utility buildings (toilets, ticket office) stylised as early medieval structures.

The entrance to the Centre is located in the gate tower. So far, remains of early medieval gates have not been discovered in Wolin. For this reason, the gate tower follows the design of the structure unearthed in Berlin-Spandau ${ }^{9}$ and the reconstruction from the Groß Raden open-air museum, which in turn was based on the discoveries made in Behren-Lübchin.

The reconstructed huts follow archaeological sources to a varying extent. Small information boards present data mainly concerning construction methods, but they lack wider context (for instance, the fact that log houses were extremely rare in Wolin and appeared only in the $11^{\text {th }}$ century, which is very unique for early medieval sites in Poland ${ }^{10}$ ). At the

${ }_{9}^{9}$ Müller A. von, Müller-Muči K. von. Die Ausgrabungen auf dem Burgwall in Berlin-Spandau. Teil 1: Textband. Berlin, 1983. S. 83.

${ }^{10}$ Cnotliwy E. 1) Pozostałości budownictwa drewnianego z IX-XII w. ze stanowiska 4 w Wolinie // Materiały Zachodnio-Pomorskie. T. VIII. 1962. S. 53-54; 2) W sprawie budownictwa we wczesnośredniowiecznym Wolinie // Materiały Zachodniopomorskie. Nowa Seria. T. IX: 2014. Z. 1: Archeologia. 2015. S. 94; Stanisławski B. Budownictwo wczesnośredniowiecznego Wolina - próba reinterpretacji // Materiały Zachodniopomorskie. Nowa Seria. T. VI/VII: 2009/2010. Z. 1: Archeologia. 2011. S. 226-228; Polak Z., Rębkowski M. Building Structures 
same time, there are buildings that have not been recorded in Wolin - e. g. a Scandinavian hut with a turf roof, based on huts from the open-air museum in Foteviken (Fig. 11), or some humoristic elements, like the sign of the Galactic Empire known from the «Star Wars» series on the rooftop of one of the huts (Fig. 12).

The landscape of the Centre also comprises other structures. Sightseeing routes lead through timber streets. The design does not state which specific archaeological discoveries were the inspiration for the streets, although their presence in Wolin is confirmed both by written records (the lives of St. Otto of Bamberg from the $12^{\text {th }}$ century ${ }^{11}$ ) and archaeological sources. There is also an impressive rampart based on one type of Wolin's historical fortifications from the beginning of the $10^{\text {th }}$ century, and a quay reconstructed according to the results of archaeological excavations, with some contemporary elements (built-in lamps).

In the middle of the inner area of the stronghold, there is a well with a well sweep. So far, no such find from the early Middle Ages has been recorded in the Wolin area, although such structures were undeniably used in that period ${ }^{12}$. The question of whether they were needed in a town located on the Dziwna Strait, with good access to water, remains open.

Located near the well, also in the inner space of the stronghold, is the sacral space. According to the original plans, this was supposed to be the site of a reconstructed temple based on the discovery made in the center of the town (site 1 trench 6). Ultimately, the religious space is demarcated by a gate, wooden idols, and a fence with curtains, behind which there is a standing sculpture representing Sventovit, similar to the so-called Światowid figurine $^{13}$ discovered in the town center. Although archaeological sources lack evidence for the existence of such organized religious space, written records confirm the presence in Wolin of a pagan temple (most probably even of several shrines) - only its location is disputed. Besides the find of a small figure with four faces, there is no evidence for the statement that Sventovit was worshipped in Wolin; according to written records, a pole with a spear stuck in it stood in the temple. It is also possible that Triglav was worshipped ${ }^{14}$. Builders of that part of the Centre may have been misled by the reconstruction (published in a popular science book $^{15}$ ) of a feature referred to as the so-called «younger temple» — with remains of a timber foundation and with a nearby discovery of a leg carved in wood. This was the basis for the claim that there was some sort of statue placed inside the building. However, that hypothesis is built on very weak grounds and has subsequently been questioned.

Some buildings were dedicated to presenting specific crafts or cultural elements of the early Middle Ages. The Centre thus holds houses of a beekeeper, a potter, a boat builder, a purse

and Spatial Organization // Wolin — the Old Town. Vol. I: Settlement Structure, Stratigraphy \& Chronology / Ed. by M. Rębkowski. Szczecin, 2019. P. 119-120.

${ }^{11}$ Kiersnowski R. Budownictwo zachodnio-pomorskie wieku XII w świetle źródeł pisanych // Wiadomości Archeologiczne. T. 19. Nr 2-4. 1953. S. 126; Rosik S. Conversio gentis Pomeranorum. Studium świadectwa o wydarzeniu (XII wiek). Wrocław, 2010.

${ }_{12}$ Biermann F., Dulinicz M. Studnia z Bochenia a problem chronologii starszych faz wczesnego średniowiecza na Mazowszu Zachodnim // Archeologia Polski. T. 46. Z. 1-2. 2001. S. 85-114.

${ }^{13}$ Filipowiak $W$. Wooden Artefacts // Wolin — the Old Town. Vol. II: Studies on Finds / Ed. by M. Rębkowski. Szczecin, 2019. P. 124.

${ }^{14}$ Rosik S. Conversio gentis Pomeranorum... S. 239-244.

${ }^{15}$ Filipowiak Wt., Gundlach H. Wolin Vineta. Die tatsächliche Legende vom Untergang und Aufstieg der Stadt. Rostock, 1992. S. 103. 
maker, a bow maker, a fisherman, a witch (Scandinavian völva), while the remaining huts are mostly «warriors' houses». At least two buildings are leased by reenactment groups («Drużyna Grodu Trzygłowa» from Szczecin and «Drużyna Wojów Wiślańskich Krak» from Kraków).

The huts are staged and furnished in a manner that is supposed to mimic daily life in the early Middle Ages (Fig. 13). It is not a permanent exhibition but rather a dynamic, fluid attempt to present the vision of that period. Most huts have very lavish interiors in terms of early medieval standards. Thus, in almost all of them one can find reconstructions of objects of Scandinavian origin, including artefacts and furniture discovered in Oseberg and Gokstad: beds, chairs, cauldrons, chests, and metal light stands (Fig. 14). Reconstructions of Slavic artefacts (including those discovered in Wolin) are mostly pottery and plain wooden objects. Therefore, the interiors do not present the realities of the early medieval Wolin, although at the same time they spark visitors' imagination and display to them the high level and quality of arts and crafts of that period.

Furthermore, decorative motifs from Scandinavia are very often used - both original designs and free interpretations thereof. In particular, such ornaments are displayed on the structural elements of huts (doors, door frames, and lintels) and on furniture (beds, benches, «thrones», etc.). While examples of Scandinavian art were indeed present in Wolin and even were created locally only on small items (spoons, handles, etc.), they constitute only a very

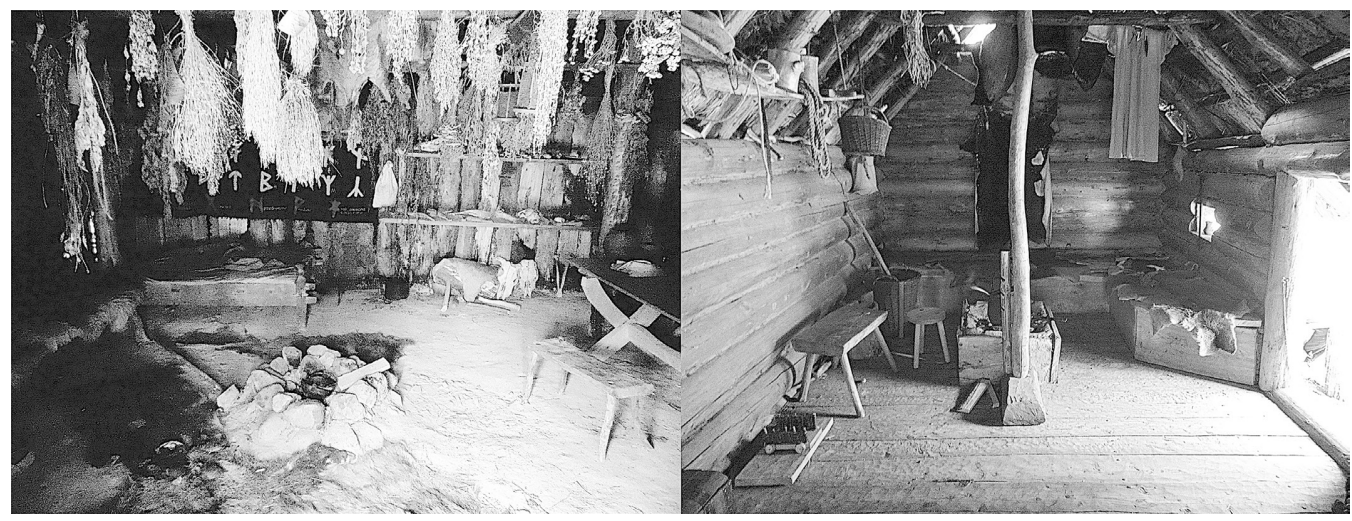

Fig. 13. Examples of the interior of the houses. Left - house of the völva, right — one of the regular houses (Foto W. Filipowiak)

small percentage of artefacts discovered at that site ${ }^{16}$. So far, there have been no discoveries of such ornamented huts - while simultaneously one will not find in the Centre decorated door frames that were not associated with Scandinavia, but which actually had been recorded in Wolin. Other elements of Viking culture include banners with runes and Scandinavian ornaments. There is also a piece of the Bayeux Tapestry with an image of King Harold Godwinson.

${ }^{16}$ Duczko W. Obecność skandynawska na Pomorzu i słowiańska w Skandynawii we wczesnym średniowieczu // Salsa Cholbergensis. Kołobrzeg w średniowieczu / Ed. by L. Leciejewicz, M. Rębkowski. Kołobrzeg, 2000. S. 23-44; Stanisławski B. Jómswikingowie z WolinaJómsborga. Studium archeologiczne przenikania kultury skandynawskiej na ziemie polskie. Wrocław, 2013. 
Furnishings that are reconstructions of archaeological artefacts (or their more-or-less free interpretation) are supplemented by items that are not based on historical sources and by contemporary objects (e. g., candles, small drums), as well as objects without any identifi-

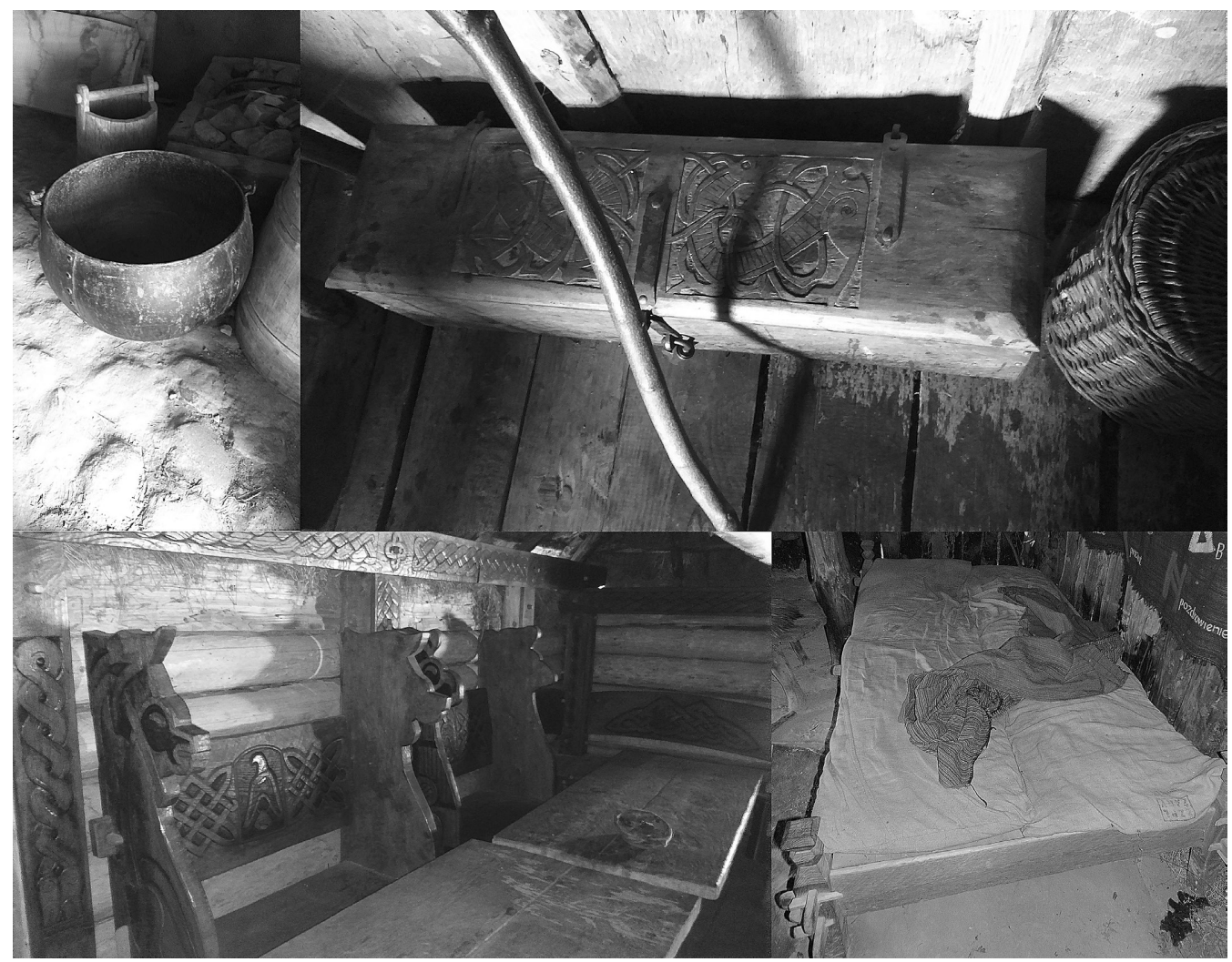

Fig. 14. Examples of objects of Scandinavian origin (Foto W. Filipowiak)

able origin. A key example are lanterns made of wood and leather, present in almost every hut, which most probably are based on the design of similar items known from $19^{\text {th }}$-century Sweden ${ }^{17}$, whereas in early medieval Wolin the most commonly-used source of light was pinewood torches ${ }^{18}$. This is the result of the specific nature of the early medieval reenactment itself, which is dominated by a kind of an «artefact fetish» - reconstruction of a specific archaeological find. For an early medieval reenactor (unlike in the case of many other recreated periods), the context of time, place, and the type of the reenacted character is less important than the number of «reconstructions» one has. The same attitude is transferred by the reenactors to their camp equipment, huts, etc. ${ }^{19}$

${ }_{17}$ URL: https://digitaltmuseum.se/011023082253/lykta (last visited - 11.08.2020).

${ }^{18}$ Filipowiak $W$. Wodden Artefacts... P. 130.

${ }^{19}$ Bogacki M. Wybrane problemy odtwórstwa wczesnośredniowiecznego w Polsce. Zagadnienia ogólne i próba charakterystyki środowiska // Kultura ludów Morza Bałtyckiego. T. II. Nowożytność i współczesność, Mare Integrans, Studia nad dziejami wybrzeży Morza Bałtyckiego: Materiały 
The Wolin Centre is more a form of a historical theme park than an actual open-air museum that would closely and realistically present a section of early medieval architecture with a broad context (e. g. house furnishings). It is a simplified form, a general illustration of the past, its vision enhanced by the display of a disproportionately large number of replicas of luxury artefacts.

\section{THE STORY}

In this prepared scenery of the Centre, the story unfolds. In principle, it is supposed to present the history of Wolin ${ }^{20}$ and the early Middle Ages in general ${ }^{21}$. In the promotional materials of the Western Pomeranian Voivodeship available at the Centre, it is described as an «open-air ethnographic museum», a supposed reconstruction of the development of Wolin between the $9^{\text {th }}$ and $11^{\text {th }}$ centuries $^{22}$. In another publication, its authors indicate that the project aims to create a reconstruction of early medieval Wolin and the culture of its inhabitants from the end of the $8^{\text {th }}$ century to the end of the $12^{\text {th }}$ century, thus including its Christian period also. That reconstruction was to cover three categories of sources: the space, types of structures, and $\operatorname{artefacts}^{23}$ - this statement is very similar to the goals formulated in the original design for the Centre created by Błażej Stanisławski ${ }^{24}$.

The main carrier of information, which made it possible to create the Centre in the first place, is the Slav and Viking Festival ${ }^{25}$. Due to its scale and international acclaim, it has tremendous influence on the visitors and reenactors' vision of early medieval Wolin. At the beginning, the main focus was the Viking history of the town and references to Jómsborg, but since 1999, as the number of participants from Poland has gradually increased and the cooperation with the academia has intensified (among others, with the Adam Mickiewicz University in Poznań), the Slavic elements of the town's history have also been incorporated and displayed. In the mid-2010s, the name of the event was extended by adding the «Slav» element and officially changed to Festiwal Stowian i Wikingów Wolin-Jomsborg-Vineta - the Wolin-Jomsborg-Vineta Slav and Viking Festival.

References to the history of the town are usually limited to the title of the Festival (changed annually according to different themes, e. g., as quotes from written records associated with the town). According to our analysis of the elements of the Festival's program, which clearly referred to Wolin's past, they often present events linked to Scandinavia (for instance, the flight of Harald Bluetooth to Wolin, the raid of the Vikings, Olaf Tryggvason in Wolin). There is also a vivid image of paganism, as one of the favourite reconstruction elements is the scene of the banishment of Bernard the monk from Wolin. The greatest number of elements of the

z III Międzynarodowej Sesji Naukowej Dziejów Ludów Morza Bałtyckiego Wolin 20-22 Lipca 2007 / Ed. by M. Bogacki, M. Franz, Z. Pilarczyk. Toruń, 2008. S. 219-269.

${ }^{20}$ URL: http://jomsborg-vineta.com/ (last visited - 11.08.2020).

${ }^{21}$ The statute of the «CENTRE OF SLAVS AND VIKINGS WOLIN-JÓMSBORG-VINETA» (CENTRUM SŁOWIAN I WIKINGÓW WOLIN-JÓMSBORG-VINETA) adopted on 20.07.2001.

${ }_{22}$ West Pomerania. Explore the Region, promotion booklet, without date. P. 12.

${ }^{23}$ Kłosowska A., Stanisławski B. Gród na wyspie... S. 26.

${ }^{24}$ Stanisławski B. Projekt «CENTRUM SŁOWIAN I WIKINGÓW WOLIN-JÓMSBORGVINETA». Archive of City Cultural Center of Wolin. CD disc.

${ }^{25}$ Bogacki M., Filipowiak W. Wolin, miasto Słowian i Wikingów. Historia wolińskich festiwali i nie tylko. Wolin, 2019. 
Festival's program associated with the history of the town was incorporated in the $22^{\text {nd }}$ edition of the event in 2016, which was set around the theme of the baptism of Wolin - although such topics are not displayed in the Centre in its day-to-day activities. The Festival's program also often includes numerous elements that are generally associated with the early medieval Slavic culture, but are not directly linked to Wolin.

Names and titles used during the event are also very characteristic: the Festival begins with a parade and a «ceremony of transferring power to the Jarl of Jomsborg». Another permanent element is a tournament in which individual warriors compete for the Jarl of Jomsborg's prize. Furthermore, in 2008, the official opening of the Centre was described in the pamphlet prepared for that ceremony as the «beginning of the construction of the Jomsborg Stronghold». Thus, the story conveyed by the Festival is to a large extent the history of the Vikings, while the Slavic element is more of an «add-on», and the history of the town is almost invisible.

Research conferences are also part of the Festival: since 2005, the Miedzynarodowa Konferencja Naukowa Dziejów Ludów Morza Battyckiego (the International Research Conference on the History of the People of the Baltic Sea Region $)^{26}$ and since 2010, the Wolińskie Spotkania Mediewistyczne (Wolin Medievalist Meetings) ${ }^{27}$. Since 2014, there also have been «reading zone» events, during which various authors, reenactors, and scientists give popular science lectures. These valuable initiatives have brought the communities of reenactors and academics closer together, although scientists still do not have any influence on the program of the Festival itself or the organisation of the Centre. At the same time, reenactors very rarely take part in discussions during research conferences and do not participate in preparing the programs for such conferences.

In addition to the Festival, the Centre also hosts other events. These include, among other things, the Young Birch Tree Festival (June), the Kupala Night (June), Honey Harvest (July), Experimental Archaeology Workshops (July), Slavic Harvest Festival (August), and Dziady («Ancestors' Eve») (August). Except for the Workshops, all of the above-mentioned events are supposed to be associated with broadly-defined Slavic culture. The Young Birch Tree Festival in the Centre is dedicated to Mokosh, the «White Lady», the «ruler of fertility, rain, and water» ${ }^{28}$. Mokosh was an Eastern Slavic deity whose role is unclear - perhaps she was a lower ranking deity, or a demon. It is possible that her worship was an extension of the ancient cult of the Earth-Mother ${ }^{29}$. It is difficult to state what source base was used to link Mokosh to a birch tree and where the worship of the young birch tree presented in the Centre came from. Perhaps it has something to do with the fact known from ethnographic sources that in the case of many Slavic tribes, primarily of the Eastern Slavs, the beginning of the spring season is named after the birch tree. It is associated with the custom of tapping the

${ }^{26}$ Organized by Adam Mickiewicz University in Poznań, the Centre, and Wolin Municipal Office.

${ }^{27}$ Organized by the Institute of Archaeology and Ethnology of the Polish Academy of Sciences, University of Szczecin, University of Wrocław, and Wolin Municipal Office.

${ }^{28}$ URL: http://jomsborg-vineta.com/swieto-mlodej-brzozy-juz-za-nami/ (last visited 12.08.2020).

${ }^{29}$ Eowmiański H. Religia Słowian i jej upadek (w. VI-XII). Warszawa, 1979. S. 123-126; Urbańczyk S. Dawni Słowianie: wiara i kult. Wrocław; Warszawa; Kraków, 1991. S. 36-39; Szyjewski A. Religia Słowian. Kraków, 2003. S. 130-131; Gieysztor A. Mitologia Słowian. Wydanie III. Warszawa, 2006. S. 201-204; Strzelczyk J. Mity, podania i wierzenia dawnych Słowian. Poznań, 2007. S. 130-131. 
so-called oskoła, i. e. birch tree $\operatorname{sap}^{30}$. During the event organized in the Centre, one can, «following the customs of the ancient Slavs, write one's wishes on the bark and hang it on birch tree branches placed in the temple in the open-air museum». It is a very interesting example of a cultural amalgamation. Fortune-telling using wreaths hanged on a birch tree is known from Rus' ${ }^{31}$, while the temple in the Centre is dedicated to Sventovit, and thus - historically speaking - to the deity from Arkona in Rügen. For this reason, we may only suspect some links between the Young Birch Tree Festival and the Stado Festival or «Green Week»" ${ }^{32}$.

A similar pattern underlines the organisation of other events that supposedly refer to «Slavic traditions» — the Kupala Night, Dziady, or the Slavic Harvest Festival. Descriptions of their programs are very brief, and the performance is close to a theatrical play. These events do not attempt to refer to traditions that exist and are still alive in Wolin - for instance, the Slavic Harvest Festival takes place two weeks before the contemporary Wolin harvest festival dożynki - organized by the Municipal Office, in which the Association takes no part.

On the surface, the Honey Harvest and the Experimental Archaeology Workshops are different, but on closer inspection they are quite similar in effect. They are both focused on the material aspect of early medieval culture (although the same items on the agenda are also presented during the festivals organized in the Centre). Both events are organized only by reenactors, and reenactors and tourists are also the only participants. The name «Experimental Archaeology Workshops» is misleading. It is linked to the current fashion among reenactors of stressing the seemingly «scientific» aspects of some of their actions ${ }^{33}$. In principle, these are «workshops on ancient crafts covering different aspects of everyday life». Yet it is, of course, hard to state which of these «ancient crafts and practices» are based on traditions handed down through generations, which are based on scientific knowledge, and which are based on the reenactors' own invention and imagination. In most cases, it is a mix of all three elements, with the preponderance of the latter, modified even further by current fashions and market forces. There is also no clear indication of items that were produced locally in Wolin and are known from archaeological excavations. «Experimental Archaeology Workshops» de facto do not have much in common with experimental archaeology - their participants are not informed about the principles and methods of this discipline and, indeed, no experiments are carried out ${ }^{34}$. We do not know any published results of experiments performed in the Centre during these «workshops» or at any other time.

Finally, in the Centre, the story is presented on a daily basis in the course of the Centre's normal activity. Visitors can tour the Centre individually or with a guide. The latter option is available on request and usually can be arranged for the following day. In the case of individual tourists, the story begins already while searching for information on the website, which presents primarily the activity of the Centre. There is no, however, information on the history of early

${ }^{30}$ Moszyński K. Kultura ludowa Słowian. T. II. Kultura duchowa. Część 1. Wydanie II. Warszawa, 1967. S. 152.

${ }^{31}$ Moszyński K. Kultura ludowa Słowian... S. 398.

${ }^{32}$ Łowmiański H. Religia Słowian... S. 234.

${ }^{33}$ Bogacki M. 1) Wybrane problemy... S. 220, 245; 2) «Wżywanie się» w przeszłość — odtwórstwo historyczne a nauka // Recepcja kultury średniowiecznej w humanistyce / Ed. by K. Obremski, J. Wenta. Toruń, 2010. S. 161-195.

${ }^{34}$ For more information about the relationships between experimental archaeology and historical reenactment see: Bogacki M. Wybrane problemy... S. 242-248. 
medieval Wolin or a detailed description of the reconstructions - unlike in the case of other similar facilities (for instance, in Foteviken ${ }^{35}$ ). Likewise, next to the entrance to the Centre there is a large display board with the spatial arrangement of buildings in the complex. For an individual tourist, the only information is presented on several small signs placed in different parts of the Centre, concerning types of buildings, the construction of the rampart or runic stones. Some more information about early medieval Wolin is provided in the introduction during guided tours or organized group tours. Here, the focus is also put on the presentation of reconstruction activities concerning various types of crafts.

\section{THE EFFECT}

What is the effect of the Centre's activities and the story presented in the Centre? Editors of this issue of Studia Slavica et Balcanica Petropolitana asked whether it is a reconstruction or a commercial fiction. In order to answer that question, first, we need to define what the Centre is.

The Wolin Centre is a historic theme park - in no way can it be described as a classic open-air museum, ethnographic (with original buildings brought together from their original locations) or archaeological (being the reconstruction of the archaeological site in a specific scale as close to the results of archaeological excavations as possible). Thus, it is difficult to use the term «open-air museum» to describe the Centre. Its aim is not to collect, document, and publish artefacts, but to present, in an attractive way, a certain image of the early Middle Ages with the use of contemporary reconstructions of objects and structures from the past.

This simplistic vision of the past means that it warped, which in some cases may lead to the dissemination of certain myths about the past. The Centre clearly presents too many elements of Viking culture, both reconstructions and free interpretations, compared to their actual presence in the early medieval Wolin. This is caused both by the genesis of the Centre, which was born out of the tradition and experience of the Viking Festival, the current Viking fashion, as well as the visual appeal of ornamented Scandinavian artefacts. The history of Wolin as a large multi-ethnic trade and craft emporium became the justification for presenting the entire early Middle Ages — usually as one big cultural melting pot into which organizers threw together different phenomena, irrespective of whether they took place in the $7^{\text {th }}$ century or the $11^{\text {th }}$ century, or if they were recorded in Western or Eastern Europe.

The objective to broaden the activities of the Association resulted in the fact that the discussed facility, to some extent, ceased to be a reconstruction of early medieval Wolin. The content presented in the Centre can be broadly defined as the early Middle Ages $^{36}$ as seen and portrayed by historical reenactors. Therefore, currently, it is not an archaeological openair museum presenting the history of Wolin. The closest appellation would be a theme park presenting the culture of Slavs and Vikings in a very general sense, according to the vision created by the reenactors.

The Centre is the embodiment of the reenactors' subculture. The same elements of material culture (either reconstructed on the basis of artefacts or without a source base at all) can

\footnotetext{
${ }^{35}$ History — URL: https://www.fotevikensmuseum.se/d/en/forskning/foteviken; buildings description - URL: https://www.fotevikensmuseum.se/d/en/museet/husen (last visited 12.08.2020).

${ }^{36}$ The style of the most recently built structures refers to the late medieval period, but they are only commercial buildings.
} 
be found in similar places both in Poland (for instance, Karpacka Troja in Trzcinica) and in Scandinavia (e. g., in Foteviken). This is a contradiction of the key mission of this type of facility, namely educating about and popularizing local history. Of course, one could adopt the view that the strong unification of the presented content is the result of the unification of the Slavic culture (or the culture of the Baltic Sea people) in the early Middle Ages. However, this is not true. There were important and visible differences, and the blended material culture presented in various facilities of that type is the result of the unification and globalisation of the reenactment movement ${ }^{37}$.

What image of early medieval Slavs is thus presented? This vision lacks any difficult elements, for instance, the role of women specific to that period, human sacrifice (of children in particular), or presenting a pre-Enlightenment mentality which, among other things, sees no difference between observation and interpretation. Generally, the vision of the Viking-Slavic culture is shown only in a form acceptable to the contemporary audience, with which modern people can positively identify themselves. For this reason, the main focus is on nature-oriented spirituality, honour, freedom, and recently also ecology. That positive identification makes it possible to incorporate such content into one's own heritage and identify it with «tradition», which would otherwise be difficult in the case of the complete set of information about the culture at that time. Only by showing the proper context could these matters be conveyed in a digestible form to the audience - however, this would require a time-consuming scientific approach. The image of medieval Slavs presented in the Centre is a depiction shaped by the reenactors' movement - dynamic, consisting of many elements of contemporary culture, with a varied degree of scientific background (i. e. relying on the results of academic research), concentrated on material culture, speculation, and the lack of methodical actions, basing interpretation primarily on «common sense». In this respect, it generally does not differ from the content presented in other facilities of this type and during reenactment events organized in Poland.

The Centre not only tries to popularize the knowledge of history but also strives to actively create cultural phenomena on its basis and merge them with modern culture, creating thus the conviction that they are «reviving» forgotten traditions. The best example are events such as the above-mentioned Young Birch Tree Festival. Cultural symbols that are used in that context come from very different areas of the broadly defined Slavia, which resembles the Pan-Slavism idea. Due to such an approach, each visitor that comes from any of the Central and Eastern European countries may identify himself/herself with the content presented in the Centre. The Scandinavian element (limited to Viking culture) facilitates identification on the part of the people who don't identify themselves as «Slavic». In that sense, the Centre is not just a place of popularisation and education - it creates new cultural content by chaotically assembling elements of history, pop culture, and modern mentality. In this manner, it becomes the creator of new meanings, with very limited foundations in actual traditions or results of academic research, which populate the vision of the past and at the same time affect contemporary actions.

Those activities are of particular importance in the case of Western Pomerania. That region was incorporated into Poland after the end of World War II, which was also associated with an almost complete replacement of the population of the region. That process caused a severe

${ }^{37}$ Bogacki M. Wybrane problemy... S. 260. 
problem concerning the lack of identification of the Poles that came to Pomerania with their new homeland ${ }^{38}$. Archaeological excavations in the second half of the $20^{\text {th }}$ century both in Pomerania and the German Democratic Republic concentrated on the Slavic history of that $\operatorname{area}^{39}$. One of the key drivers behind such an approach was the attempt to «build bridges» between the early Middle Ages and the modern period and provide the repatriants with foundations on which they could build their regional identity ${ }^{40}$. The absence of ties with the history of Pomerania and the conviction about its German character resulted in the lack of respect for the past and historic monuments, particularly in the context of the uncertainty as to the actual shape of state borders. Despite heroic efforts on the part of heritage protection services, archaeologists, historians, and ethnographers, many priceless monuments and finds were lost.

The modern generation of Pomeranians, free from the burden of war trauma and the yoke of the communist system, feels a very strong need to have a regional identity ${ }^{41}$. For this reason, all operations on this «mental tissue» should be performed with much consideration, prudence, and knowledge. At the same time there is a visible absence of academics in the public forum - both in the form of popular science publications and official, organized (institutional) activities. The Andrzej Kaube Regional Museum in Wolin, due to its limited funding, has not been able to compensate for those gaps.

In this situation, activities carried out by the Centre are extremely important and have a particular influence. The Centre is one of the few institutions of its kind fully managed by a private association of reenactors. For this reason, their actions are very dynamic and visually attractive, and respond extremely well to the needs of the historical reenactment movement (for example, during the organisation of the Slav and Viking Festival). At the same time, due to the lack of visible cooperation with heritage professionals, archaeologists, historians, ethnographers, or museum professionals, and no participation in bodies and organisations that bring together similar sites and institutions, such as EXARC or the Open-Air Museum Association (Polish: Stowarzyszenie Muzeów na Wolnym Powietrzu), their actions are chaotic and confuse tradition with reconstruction, history with fiction, archaeology with craft, and finally science with speculation. As a result, the line between how it was and how it might have been is too easily crossed.

The average addressee of the content presented by the Centre is convinced that this content is carefully selected on the grounds of historical knowledge, consulted with professionals and that it is some sort of «true tradition». Simultaneously, it is presented in a very attractive way and reaches a very large audience. Therefore, in Western Pomerania, with its severe identity crisis, there is a real risk that the message created by the reenactment movement subculture will replace real traditions and scientific achievements.

${ }^{38}$ Kledzik E., Michalski M., Praczyk M. (eds). «Ziemie Odzyskane». W poszukiwaniu nowych narracji. Poznań, 2018.

${ }^{39}$ Lech J. Between captivity and freedom: Polish archaeology in the $20^{\text {th }}$ century // Archaeologia Polona. Vol. 35/36 (1997/1998). 1998. P. 25-222; Rębkowski M. Badania milenijne na Pomorzu Zachodnim. Przebieg, znaczenie, skutki // Przegląd Archeologiczny. T. 65. 2017. S. 117-131.

${ }^{40}$ Migdalski P. Pamięć pomorska po 1945 roku // Przegląd Uniwersytecki. Pismo Uniwersytetu Szczecińskiego. Nr 10-12 (287-289). 2016. S. 35.

${ }^{41}$ Migdalski P. Kilka refleksji o tożsamości Pomorza // Przegląd Uniwersytecki. Pismo Uniwersytetu Szczecińskiego. Nr 4-6 (293-295). 2017. S. 22. 
The results of archaeological excavations and historical research on Wolin were the reason for its international fame and recognition. Local authorities, to a varying extent, see the history of the town as one of the key elements of its promotion. Since the establishment of the Festival, and later the Centre, the early medieval history of Wolin has been identified with these two institutions. The Centre has also become one of the main tourist attractions of Western Pomerania, actively promoted by regional authorities - which proves the thesis that it is treated as the «carrier of traditions». For years the town authorities have supported the organisation of the Festival. A local development plan for the Wolin district was even drawn up, which was supposed to have been implemented by 2013. The part concerning cultural heritage titled «Wolin — a town of history» was prepared by archaeologist Błażej Stanisławski. That plan assumed a comprehensive development of tourism based on the cooperation between cultural and educational institutions. It is an interesting example of the theses presented in this paper. Wolin is a town with a rich history of its own - but it has become a town of history in general. In Wolin, all of this resulted in a situation which we could describe as the «privatization of heritage». Open-air events organized by public institutions from 1972-1992 were «inward-facing», widely engaging residents of the town itself but also attracting people that lived in villages of the Wolin district. The change came together with the establishment of the Festival and the Centre, organized and managed by a small group of members of the Association. The Festival is «outward-facing», aimed at tourists and a mass audience. Most local residents do not identify themselves with the activity carried out by the Centre, which also manifests in tangible ways. The Festival is divided into the so-called «historic» part, $\mathrm{i}$. e. taking place in the Centre and organized by the Association, and the part for the local community, which is organized on the other bank of the Dziwna Strait by the Municipal Cultural Centre (usually only loosely linked to the Festival itself). The dividing line between the two is the Dziwna Strait ${ }^{42}$.

The «privatization of heritage» occurred also as a result of the weakness of public institutions, primarily of the Regional Museum, which was not able to compete against the wellfunded and promoted Centre and the mass event that is the Festival ${ }^{43}$. The activity of the reenactors, because of that weakness, started to gradually swallow up successive areas of Wolin's common cultural heritage located even in the town center: information boards dedicated to the early medieval harbour were taken over from the Museum; there were also plans for the Association to take over the management of the Museum itself (while the Association consists of history lovers, they are not heritage professionals), create an Ethnographic Museum in new buildings, and to manage archaeological sites located in the town area. It is a process that may cause even further detachment of the local community from the history of the town, as only public institutions, due to their nature, are egalitarian, accessible to all, constitute common

${ }^{42}$ Antagonism understood as the divide between the historical part and the fair, as a dispute between members of the Association and local residents, and between reenactors arriving in large groups for the Festival and «civilians» who do not take part in that movement.

${ }^{43}$ It is the opposite process to the situation in countries that have never experienced the communist system. There we see the process of transferring important heritage sites from private hands under the management of state institutions or foundations specialising in heritage protection: Stepień P. M. Kryzys teorii — czy kryzys praktyki? Co powinniśmy naprawić w systemie ochrony dziedzictwa architektonicznego // Współczesne problemy teorii konserwatorskiej w Polsce / Ed. by B. Szmygin. Lublin, 2008. S. 129. 
property and usually are managed by professionals. Cultural heritage is public property and as such, it is subject to the rule of public control of the way in which it is used. The principle of common responsibility applies both to amateur heritage enthusiasts and professionals ${ }^{44}$.

All the above-mentioned comments do not change the fact that initiatives such as the Wolin Festival and the Centre are these days particularly valuable in the popularisation of history. Of course, one can have objections as to the scientific approach and content, which in museums as a rule is much stricter and on a much higher level, but at the same time it is impossible to deny their ability to play on the audience's emotions which increases their popular appeal. Here, museum professionals and scientists could learn a lot in terms of getting through to the audience in an interesting and clear manner ${ }^{45}$.

\section{Conclusions}

The Slav and Viking Festival, one of the largest events of its kind in Europe, has become a primary destination for early medieval reenactors. The Centre of Slavs and Vikings, which was born as a result of the Festival's success, is unique, as it is run by a private association of reenactors and not a public institution. In itself, the fact that such a big project as the Festival and the Centre have been maintained for the last 25 years (in the case of the Centre slightly less time) is a tremendous achievement on the part of a small town with a very limited budget.

However, the success of these undertakings and their professionalisation in terms of mass tourism have become their greatest burden. The price for the success was the loss of regional character and transformation into an early medieval theme park. As a result of the lack of a professional approach and no real cooperation with scholars with respect to the content presented, they have become limited to the actions and ideas of the reenactors and, as a consequence, suppressed the interest of local residents in the real history of their own town and region. Of course, this is not entirely the fault of the reenactors themselves, but rather of the lack of balance between their actions and input from scientists and museum professionals:

«The history of Wolin for years has been believed to be the town's most valuable resource. It can be compared to gold, since - like gold - the history of Wolin can be dug out. There is the Archaeological Workshop of the Institute of Archaeology and Ethnology of the Polish Academy of Sciences, employees of which since 1952 have been studying the town's past. This is the goldmine and the design lab. The Andrzej Kaube Regional Museum is the treasury, while the Wolin-Jomsborg-Vineta Slav and Viking Centre Association and the open-air museum are jewellers' workshops that turn gold into trinkets and ornaments, and these sell best. The Festival and conferences - are jewellers' fairs. If we look at the situation in this manner it becomes clear that none of the above-mentioned elements can function without the others. Without excavations, there will be no supply of gold or designs for future products. Without an efficient treasury, gold will be taken over by others or will be irretrievably lost» ${ }^{46}$.

${ }^{44}$ Kobyliński Z. Czym jest, komu jest potrzebne i do kogo należy dziedzictwo kulturowe? // Mazowsze. Studia regionalne. Nr 7. 2011. S. 36.

${ }^{45}$ Bogacki M. «Wżywanie się»... S. 161-195.

${ }^{46}$ Bogacki M., Filipowiak W. Wolin, miasto Słowian... S. 192. 
Информация о статье

Авторы: Филиповяк, Войцех — доктор археологии, адьюнкт, Институт археологии и этнологии, Польская академия наук, Волин, Польша, OrcID 0000-0002-1646-2969; e-mail: w.filipowiak@iaepan.szczecin.pl; Богацки, Михаль - доктор истории, директор, Музей истоков Польского государства в Гнезно, Гнезно, Польша; e-mail: michal.bogacki@muzeumgniezno.pl;

Кокора, Каролина — магистр археологии и истории, директор, Региональный музей в Волине, Волин, Польша, OrcID 0000-0002-4663-7416; e-mail: kokora.karolina@gmail.com

Заголовок: The Center of Slavs and Vikings in Wolin, Poland. History, scenography, story and efect [Центр славян и скандинавов в Волине, Польша. История и вымысел, театральность и эффект]

Резюме: В данной статье авторы анализируют реконструкцию древнего Волина, крупного славяно-скандинавского центра, представленного в настоящее время как музей под открытым небом (далее - Центр). Реконструкция была проведена на острове в проливе Дзивна, напротив центра Волина. В раннем Средневековье город был одним из крупнейших ремесленных и торговых центров Балтики. История Волина связана с легендами о Йомсборге и Винете, город упоминается в многочисленных письменных источниках и уже почти 200 лет является объектом археологических исследований. Идея строительства археологического и этнографического музея под открытым небом появилась среди археологов в 1958 г. По разным причинам этот проект не был реализован в период существования Польской Народной Республики. В 1992 г. состоялся «Фестиваль викингов» (сегодня «Фестиваль славян и викингов»), известный сейчас как одно из крупнейших реконструкторских мероприятий в Европе. По мере развития фестиваля создавались и элементы его декораций. В 2002 г. возникла ассоциация славян и викингов «Волин-Йомсборг-Винета», главной целью которой было строительство исторического центра. Он был открыт в 2008 г. и продолжает развиваться по сей день. Исторический парк представляет собой упрощенную картину раннего Средневековья с небольшим уклоном в историю города и региона. Успех «Фестиваля славян и викингов», равно как и рост популярности места его проведения, стал и самым большим его недостатком, так как фестиваль перестал быть реконструкцией раннесредневекового Волина. Это привело к утрате оригинальности, а также упрощению образа славян, который усваивается современным зрителем, 一 акцент делается на духовность, связь с природой, мужество, честь, свободу, экологичность. С другой стороны, игнорируется ряд аспектов (например, подчиненная роль женщины), которые были бы неприемлемы в современной культуре. Отсутствие сотрудничества с профессионалами делает деятельность Центра хаотичной - смешивается понятие национальной традиции с реконструкцией, история с выдумкой, археология с ремеслом и, наконец, наука с догадками. Создание нового содержания на основе избирательного исторического знания и представление его как «возрожденных традиций» требует особого внимания в Западной Померании, где после 1945 г. возникла реальная проблема региональной идентичности. Центр, управляемый частной ассоциацией, динамично развивается и имеет успех в туристическом бизнесе. Это привело к «приватизации наследия», с которым большинство жителей региона себя не отождествляет. Для противодействия этому авторы постулируют усиление сотрудничества между частными структурами (Ассоциацией, Центром) и государственными учреждениями (музеем, Институтом археологии и этнологии Польской академии наук).

Ключевые слова: Волин, Польша, музей под открытым небом, историческая реконструкция, раннее Средневековье, исследования Средневековья, исследования культуры, реконсрукция, музей

\section{Литература, использованная в статье:}

Biermann, Felix; Dulinicz, Marek. Studnia z Bochenia a problem chronologii starszych faz wczesnego średniowiecza na Mazowszu Zachodnim // Archeologia Polski. 2001. T. 46. Z. 1-2. S. 85-114.

Bogacki, Michat. Wybrane problemy odtwórstwa wczesnośredniowiecznego w Polsce. Zagadnienia ogólne i próba charakterystyki środowiska // Kultura ludów Morza Bałtyckiego. T. II. Nowożytność i współczesność. Mare Integrans. Studia nad dziejami wybrzeży Morza Bałtyckiego. Materiały z III Międzynarodowej Sesji Naukowej Dziejów Ludów Morza Bałtyckiego Wolin 20-22 Lipca 2007 / Ed. by Bogacki, Michał; Franz, Maciej; Pilarczyk, Zbigniew. Toruń: Wydawnictwo Adam Marszałek, 2008. S. 219-269.

Bogacki, Michat. «Wżywanie się»w przeszłość — odtwórstwo historyczne a nauka // Recepcja kultury średniowiecznej w humanistyce / Ed. by Obremski, Krzysztof; Wenta, Jarosław. Toruń: Wydawnictwo Naukowe Uniwersytetu Mikołaja Kopernika, 2010. S. 161-195.

Bogacki, Michat; Filipowiak, Wojciech. Wolin, miasto Słowian i Wikingów. Historia wolińskich festiwali i nie tylko. Wolin: Urząd Miasta i Gminy Wolin, 2019. 196 s. 
Cnotliwy, Eugeniusz. Pozostałości budownictwa drewnianego z IX-XII w. ze stanowiska 4 w Wolinie// Materiały Zachodnio-Pomorskie. 1962. T. VIII. S. 29-84.

Cnotliwy, Eugeniusz. W sprawie budownictwa we wczesnośredniowiecznym Wolinie // Materiały Zachodniopomorskie. Nowa Seria. 2015. T. IX. 2014. Z. 1: Archeologia. S. 94.

Duczko, Władysław. Obecność skandynawska na Pomorzu i słowiańska w Skandynawii we wczesnym średniowieczu // Salsa Cholbergensis. Kołobrzeg w średniowieczu / Ed. by Leciejewicz, Lech; Rębkowski, Marian. Kołobrzeg: Le Petit Café, 2000. S. 23-44.

Filipowiak, Wojciech. Wooden Artefacts // Wolin - the Old Town. Vol. II: Studies on Finds / Ed. by Rębkowski, Marian. Szczecin: IAE PAN, 2019. P. 89-135.

Filipowiak, Władystaw; Konopka, Marek. The identity of a Town. Wolin, Town-State- $9^{\text {th }}-12^{\text {th }}$ Centuries // Quaestiones Medii Aevii Novae. 2008. Vol. 13. P. 243-288.

Gerlach-Jósewicz, Alicja. Koncepcja wolińskiego parku etnograficznego-archeologicznego // Jantarowe Szlaki. 1976. R. 19. Nr 4-5 (154-155). S. 58-60.

Gieysztor, Aleksander. Mitologia Słowian. Wydanie III. Warszawa: Wydawnictwa Uniwersytetu Warszawskiego, 2006. 407 s.

Kledzik, Emilia; Michalski, Maciej; Praczyk, Małgorzata (eds). «Ziemie Odzyskane». W poszukiwaniu nowych narracji. Poznań: Instytut Historii UAM, 2018. 522 s.

Kiersnowski, Ryszard. Budownictwo zachodnio-pomorskie wieku XII w świetle źródeł pisanych // Wiadomości Archeologiczne. 1953. T. 19. Nr 2-4. S. 105-135.

Kłosowska, Agnieszka; Stanisławski, Błażej. Gród na wyspie // Gazeta Rycerska. Wydanie Specjalne. 2008. S. 26-28.

Kobyliński, Zbigniew. Czym jest, komu jest potrzebne i do kogo należy dziedzictwo kulturowe? // Mazowsze. Studia regionalne. 2011. Nr 7. S. 21-47.

Lech, Jacek. Between captivity and freedom: Polish archaeology in the $20^{\text {th }}$ century // Archaeologia Polona. 1998. Vol. 35/36 (1997/1998). P. 25-222.

Łowmiański, Henryk. Religia Słowian i jej upadek (w. VI-XII). Warszawa: Państwowe Wydawnictwo Naukowe, 1979. $433 \mathrm{~s}$.

Migdalski, Pawet. Pamięć pomorska po 1945 roku // Przegląd Uniwersytecki. Pismo Uniwersytetu Szczecińskiego. 2016. Nr 10-12 (287-289). S. 34-38.

Migdalski, Pawet. Kilka refleksji o tożsamości Pomorza // Przegląd Uniwersytecki. Pismo Uniwersytetu Szczecińskiego. 2017. Nr 4-6 (293-295). S. 19-23.

Moszyński, Kazimierz. Kultura ludowa Słowian. T. II. Kultura duchowa. Część 1. Wydanie II. Warszawa: Książka i Wiedza, 1967. 833 s.

Müller, Adriaan von; Müller-Muči, Klara von. Die Ausgrabungen auf dem Burgwall in Berlin-Spandau. Teil 1: Textband. Berlin: Verlag Volker-Spiess, 1983. (Berliner Beiträge zur Vor- und Frühgeschichte Neue Folge. Bd 3). $170 \mathrm{~s}$.

Polak, Zbigniew; Rębkowski, Marian. Building Structures and Spatial Organization // Wolin - the Old Town. Vol. I: Settlement Structure, Stratigraphy \& Chronology / Ed. by Rębkowski, Marian. Szczecin: IAE PAN, 2019. S. 115-131.

Rębkowski, Marian. Badania milenijne na Pomorzu Zachodnim. Przebieg, znaczenie, skutki // Przegląd Archeologiczny. 2017. T. 65. S. 117-131.

Rębkowski, Marian (ed.). Wolin — the Old Town. In 2 vol. Szczecin: IAE PAN, 2019.

Rosik, Stanisław. Conversio gentis Pomeranorum. Studium świadectwa o wydarzeniu (XII wiek). Wrocław: Chronicon, 2010. $710 \mathrm{~s}$.

Stęień, Piotr M. Kryzys teorii - czy kryzys praktyki? Co powinniśmy naprawić w systemie ochrony dziedzictwa architektonicznego // Współczesne problemy teorii konserwatorskiej w Polsce / Ed. by Szmygin, Bogusław. Lublin: Wydawnictwo Politechniki Lubelskiej, 2008. S. 121-132.

Stanisławski, Błażej. Budownictwo wczesnośredniowiecznego Wolina - próba reinterpretacji // Materiały Zachodniopomorskie. Nowa Seria. 2011. T. VI/VII: 2009/2010. Z. 1: Archeologia. S. 223-268.

Stanisławski, Błażej. Jómswikingowie z Wolina-Jómsborga. Studium archeologiczne przenikania kultury skandynawskiej na ziemie polskie. Wrocław: IAE PAN, 2013. $355 \mathrm{~s}$.

Stanisławski, Błażej; Filipowiak, Władysław (eds). Wolin wczesnośredniowieczny. Część 1. Warszawa: Trio, 2013. (Origines Polonorum. T. 6). 370 s.

Stanisławski, Błażej; Filipowiak, Władysław (eds). Wolin wczesnośredniowieczny. Część 2. Warszawa: Trio, 2014. (Origines Polonorum. T. 7). 459 s. 
Strzelczyk, Jerzy. Mity, podania i wierzenia dawnych Słowian. Poznań: Dom Wydawniczy Rebis sp. z o. o., 2007. $265 \mathrm{~s}$.

Szyjewski, Andrzej. Religia Słowian. Kraków: Wydawnictwo WAM, 2003. 268 s.

Urbańczyk, Stanisław. Dawni Słowianie: wiara i kult. Wrocław; Warszawa; Kraków: Zakład Narodowy im. Ossolińskich - Wydawnictwo Polskiej Akademii Nauk, 1991. 222 s.

Information about the article

Authors: Filipowiak, Wojciech — PhD in Archaeology, Adjunct, Institute of Archaeology and Ethnology, Polish Academy of Sciences, Wolin, Poland, OrcID 0000-0002-1646-2969; e-mail: w.filipowiak@iaepan.szczecin.pl; Bogacki, Michał - PhD in History, Director, Museum of the Origins of Polish State in Gniezno, Gniezno, Poland; e-mail: michal.bogacki@muzeumgniezno.pl;

Kokora, Karolina - MA in Archaeology and History, Director, Regional Museum in Wolin, Wolin, Poland, OrcID 0000-0002-4663-7416; e-mail: kokora.karolina@gmail.com

Title: The center of Slavs and Vikings in Wolin, Poland. History, scenography, story and effect

Summary: In this paper, the authors analyze the Center of Slavs and Vikings (hereinafter Centrum), a reconstruction of early medieval Wolin functioning as an open air museum. The reconstruction was made on an islet on the Dziwna Strait, opposite the center of Wolin. In the early Middle Ages, the city was one of the largest craft and trade centers on the Baltic Sea. It appears in numerous written sources and has been the subject of archaeological research for nearly 200 years. Its history is connected with the legend of Jómsborg and Vineta. The idea of building an archaeological and ethnographic open-air museum was established in 1958 in archaeological circles. For various reasons, this intention was not realized during the period of the Polish People's Republic. In 1992, the Viking Festival (today the Festival of Slavs and Vikings) was initially organized in Wolin, which is now one of the largest reenactors' events in Europe. As the festival developed, elements of its scenery were created. In 2002, the local Wolin-Jomsborg-Vineta Center of Slavs and Vikings Association was registered with the aim of building the Center. It was opened in 2008 and has been gradually expanding with new elements. The center is a historical park that presents a simplified vision of the early Middle Ages, with little reference to the history of the city and the region. The success of the Slavs and Vikings Festival and the Center became its greatest disadvantage - it ceased to be a reconstruction of early medieval Wolin. The content presented there is related to the subculture of performers and as such is not original - similar forms can be found in other facilities of this type in Poland and abroad. The presented image of the Slavs is simplified in a way that is assimilable to the contemporary recipient - the emphasis is on nature-related spirituality, courage, honor, freedom, ecology. On the other hand, content that would be unacceptable in contemporary culture (e. g. the role of women) is omitted. The lack of cooperation with professionals makes the activities of the Center chaotic, confusing the notion of tradition with reconstruction, history with story, archeology with handicraft, and finally science with guesswork. Creating new content on the basis of selective historical knowledge and presenting it as «revived traditions» requires special attention in Western Pomerania, where due to the population exchange after 1945 there is a real problem of regional identity. The center, run by a private association, is dynamic and is a success as a product of promotion and tourism. Nevertheless, its success resulted in the «privatization of heritage», which most of the region's inhabitants do not identify with. To counteract this, the authors postulate increasing cooperation between private entities (Association, Center) and public institutions (the Museum, Institute of Archeology and Ethnology of the Polish Academy of Sciences).

Keywords: Wolin, Poland, open-air museum, historical reenactment, early Middle Ages, cultural studies

\section{References:}

Biermann, Felix; Dulinicz, Marek. Studnia z Bochenia a problem chronologii starszych faz wczesnego średniowiecza na Mazowszu Zachodnim [The Well of Bochenia and the problem of chronology of older phases of the early Middle Ages in Western Mazovia], in Archeologia Polski. 2001. T. 46. Z. 1-2. Pp. 85-114. (in Polish).

Bogacki, Michał. Wybrane problemy odtwórstwa wczesnośredniowiecznego w Polsce. Zagadnienia ogólne i próba charakterystyki środowiska [Selected problems of early medieval reenactment in Poland. General issues and an attempt to characterize the movement], in Bogacki, Michał; Franz, Maciej; Pilarczyk, Zbigniew (eds). Kultura ludów Morza Bałtyckiego. T. II. Nowożytność i współczesność. Mare Integrans. Studia nad dziejami wybrzeży Morza Bałtyckiego. Materiały z III Międzynarodowej Sesji Naukowej Dziejów Ludów Morza Bałtyckiego Wolin 20-22 Lipca 2007. Toruń: Adam Marszałek Publ., 2008. Pp. 219-269. (in Polish). 
Bogacki, Michał. «Wżywanie się» w przeszłość — odtwórstwo historyczne a nauka [«Living» in the past — historical reenactment and science], in Obremski, Krzysztof; Wenta, Jarosław (eds). Recepcja kultury średniowiecznej w humanistyce. Torun: The Nicolaus Copernicus University Press, 2010. Pp. 161-195. (in Polish).

Bogacki, Michał; Filipowiak, Wojciech. Wolin, miasto Stowian $i$ Wikingów. Historia wolińskich festiwali $i$ nie tylko [Wolin, the city of Slavs and Vikings. The history of Wolin festivals and more]. Wolin: Urząd Miasta i Gminy Wolin Pub., 2019. 196 p. (in Polish).

Cnotliwy, Eugeniusz. Pozostałości budownictwa drewnianego z IX-XII w. ze stanowiska 4 w Wolinie [The remains of wooden constructions from the $9^{\text {th }}-12^{\text {th }}$ centuries from site 4 in Wolin], in Materiaty Zachodnio-Pomorskie. 1962. T. VIII. Pp. 29-84. (in Polish).

Cnotliwy, Eugeniusz. W sprawie budownictwa we wczesnośredniowiecznym Wolinie [On constructions in early medieval Wolin], in Materiaty Zachodniopomorskie. Nowa Seria. 2015. T. IX: 2014. Z. 1: Archeologia. P. 94. (in Polish).

Duczko, Władysław. Obecność skandynawska na Pomorzu i słowiańska w Skandynawii we wczesnym średniowieczu [Scandinavian presence in Pomerania and Slavic presence in Scandinavia in the early Middle Ages], in Leciejewicz, Lech; Rębkowski, Marian (eds). Salsa Cholbergensis. Kołobrzeg w średniowieczu. Kołobrzeg: Le Petit Café Publ., 2000. Pp. 23-44. (in Polish).

Filipowiak, Wojciech. Wooden Artefacts, in Rębkowski, Marian (ed.). Wolin — the Old Town. Vol. II: Studies on Finds. Szczecin: IAE PAN Publ., 2019. Pp. 89-135.

Filipowiak, Władysław; Konopka, Marek. The identity of a Town. Wolin, Town-State $9^{\text {th }}-12^{\text {th }}$ centuries, in Quaestiones Medii Aevii Novae. 2008. Vol. 13. Pp. 243-288.

Gerlach-Jósewicz, Alicja. Koncepcja wolińskiego parku etnograficznego-archeologicznego [The concept of the Wolin ethnographic and archaeological park], in Jantarowe Szlaki. 1976. R. 19. Nr 4-5 (154-155). Pp. 58-60. (in Polish).

Gieysztor, Aleksander. Mitologia Stowian [Slavic mythology]. Wydanie III. Warszawa: The University of Warsaw Press, 2006. 407 p. (in Polish).

Kledzik, Emilia; Michalski, Maciej; Praczyk, Małgorzata (eds). «Ziemie Odzyskane». W poszukiwaniu nowych narracji [ «Regained Territories». In search of new narratives]. Poznań: Institute of History AMU Press, 2018. 522 p. (in Polish).

Kiersnowski, Ryszard. Budownictwo zachodnio-pomorskie wieku XII w świetle źródeł pisanych [West Pomeranian constructions of the $12^{\text {th }}$ century in the light of written sources], in Wiadomości Archeologiczne. 1953. T. 19. Nr 2-4. Pp. 105-135. (in Polish).

Kłosowska, Agnieszka; Stanisławski, Błażej. Gród na wyspie [Gord on the island], in Gazeta Rycerska. Wydanie Specjalne. 2008. Pp. 26-28. (in Polish).

Kobyliński, Zbigniew. Czym jest, komu jest potrzebne i do kogo należy dziedzictwo kulturowe? [What is it, who needs it and to whom does the cultural heritage belong?], in Mazowsze. Studia regionalne. 2011. $\mathrm{Nr} 7$. Pp. 21-47. (in Polish).

Lech, Jacek. Between captivity and freedom: Polish archaeology in the $20^{\text {th }}$ century, in Archaeologia Polona. 1998. Vol. 35/36 (1997/1998). Pp. 25-222.

Łowmiański, Henryk. Religia Stowian i jej upadek (w. VI-XII) [The religion of the Slavs and its fall $\left(6^{\text {th }}-12^{\text {th }}\right.$ centuries) ]. Warszawa: Państwowe Wydawnictwo Naukowe Publ., 1979. 433 p. (in Polish).

Migdalski, Paweł. Pamięć pomorska po 1945 roku [Pomeranian memory after 1945], in Przegląd Uniwersytecki. Pismo Uniwersytetu Szczecińskiego. 2016. Nr 10-12 (287-289). Pp. 34-38. (in Polish).

Migdalski, Paweł. Kilka refleksji o tożsamości Pomorza [A few reflections on the identity of Pomerania], in Przeglad Uniwersytecki. Pismo Uniwersytetu Szczecińskiego. 2017. Nr 4-6 (293-295). Pp. 19-23. (in Polish).

Moszyński, Kazimierz. Kultura ludowa Stowian. T. II. Kultura duchowa. Część 1 [Folk culture of the Slavs. Volume II. Spiritual Culture. Part 1]. Wydanie II. Warszawa: Książka i Wiedza Publ., 1967. 833 p. (in Polish).

Müller, Adriaan von; Müller-Muči, Klara von. Die Ausgrabungen auf dem Burgwall in Berlin-Spandau. Teil 1: Textband [The excavations on the gord in Berlin-Spandau. Part 1: text]. Berlin: Volker-Spiess Publ., 1983. (Berliner Beiträge zur Vor- und Frühgeschichte Neue Folge. Bd 3). 170 p. (in German).

Polak, Zbigniew; Rębkowski, Marian. Building structures and spatial organization, in Rębkowski, Marian (ed.). Wolin - the Old Town. Vol. I: Settlement structure, stratigraphy \& chronology. Szczecin: IAE PAN Publ., 2019. Pp. 115-131. 
Rębkowski, Marian. Badania milenijne na Pomorzu Zachodnim. Przebieg, znaczenie, skutki [Millennium Research in Western Pomerania. Course, meaning, effects], in Przeglad Archeologiczny. 2017. T. 65. Pp. 117-131. (in Polish).

Rębkowski, Marian (ed.). Wolin - the Old Town. In 2 vol. Szczecin: IAE PAN Publ., 2019.

Rosik, Stanisław. Conversio gentis Pomeranorum. Studium świadectwa o wydarzeniu (XII wiek) [Conversio gentis Pomeranorum. Study of a testimony on an event (12 $2^{\text {th }}$ century)]. Wrocław: Chronicon Publ., 2010. 710 p. (in Polish).

Stępień, Piotr M. Kryzys teorii — czy kryzys praktyki? Co powinniśmy naprawić w systemie ochrony dziedzictwa architektonicznego [Crisis of theory - or crisis of practice? What should we fix in the architectural heritage protection system], in Szmygin, Bogusław (ed.). Wspótczesne problemy teorii konserwatorskiej w Polsce. Lublin: Wydawnictwo Politechniki Lubelskiej Publ., 2008. Pp. 121-132. (in Polish).

Stanisławski, Błażej. Budownictwo wczesnośredniowiecznego Wolina — próba reinterpretacji [Early medieval construction in Wolin - a reinterpretation attempt], in Materialy Zachodniopomorskie. Nowa Seria. 2011. T. VI/VII: 2009/2010. Z. 1: Archeologia. Pp. 223-268. (in Polish).

Stanisławski, Błażej. Jómswikingowie z Wolina-Jómsborga. Studium archeologiczne przenikania kultury skandynawskiej na ziemie polskie [Jómswikings from Wolin-Jómsborg. Archaeological study of the penetration of Scandinavian culture into Poland]. Wrocław: IAE PAN Publ., 2013. 355 p. (in Polish).

Stanisławski, Błażej; Filipowiak, Władysław (eds). Wolin wczesnośredniowieczny. Część 1 [Early medieval Wolin. Part 1]. Warszawa: Trio Publ., 2013. (Origines Polonorum. T. 6). 370 p. (in Polish).

Stanisławski, Błażej; Filipowiak, Władysław (eds). Wolin wczesnośredniowieczny. Część 2 [Early medieval Wolin. Part 2]. Warszawa: Trio Publ., 2014. (Origines Polonorum. T. 7). 459 p. (in Polish).

Strzelczyk, Jerzy. Mity, podania i wierzenia dawnych Stowian [Myths, traditions and beliefs of former Slavs]. Poznań: Dom Wydawniczy Rebis sp. z o. o. Publ., 2007. 265 p. (in Polish).

Szyjewski, Andrzej. Religia Stowian [Religion of the Slavs]. Kraków: WAM Publ., 2003. 268 p. (in Polish). Urbańczyk, Stanisław. Dawni Stowianie: wiara i kult [Former Slavs: faith and worship]. Wrocław; Warszawa; Kraków: Zakład Narodowy im. Ossolińskich — the Polish Academy of Sciences Press, 1991. 222 p. (in Polish). 